\title{
Multicultural South African children's literature: reflections of a changing society
}

\author{
SANDRA OLËN \\ Department of Information Science, University of South Africa, \\ PO Box 392, Pretoria 0003, Republic of South Africa, e-mail \\ olensii@alpha.unisa.ac.za
}

\begin{abstract}
Twenty multicultural youth novels published in South Africa in English from 1994 to 1997 are analysed to determine how they reflect cultural values and social changes. This period is significant because for the first time a majority govemment is in power and "apartheid" is being dismantled. The novels deal with topics such as integration in schools and communities, poverty, homelessness, drug and child abuse, crime and violence, illegal immigrants, sexual relationships and different cultural values. Works by African authors reflect township life and raise the issue of the often unquestioning acceptance of many Westem cultural values by young Africans.
\end{abstract}

\section{Introduction}

On 27 April 1994 the first democratic elections were held in South Africa and this effectively ended the rule of the black majority by a small white minority. Since the election the majority party in parliament has been the African National Congress (ANC) and its policy has been one of equity, redress and reconciliation. Some of the results of this policy have been greater integration in the schools and in residential areas; affirmative action; a relaxation in the censorship laws; and an emphasis on transparency and people's right to information.

Van der Walt (1994) has already explored the nature of the relationship between South African society and some contemporary realistic South African English youth novels published prior to 1994. It is the intention of this paper to analyze a number of multicultural youth novels, many of which have received local awards, that were published in South Africa in English from 1994 to 1997 to determine how they reflect the social changes. This period, although short, is significant in the history of the country, because of the many political and social changes that have taken place.

\section{Moving from segregation to integration}

Several researchers and writers on literature for children and youth have shown how inevitable it is that the values and ideologies held by authors will be conveyed in their texts

Education for All: Culture, Reading and Information, IASL, 1998 
(Brown, 1983; Hollindale, 1992; Machet \& Bester, 1990; Macleod, 1975; Shannon, 1986). Mitchell and Smith (1996) have also asked whether literature for young people can contribute to social change. During the apartheid era the segregation of races meant little or no social contact with other groups. Young adults in recently published novels, for example Boikie, You Better Believe It! (Hofmeyr, 1994), The Red-haired Khumalo (Bregin 1994), Dark Waters (Robson, 1995), One Magic Moment (Robson 1996), Moongirl (Smith, 1996) and Jakey (Beake, 1997), have friends and neighbors who are from different ethnic and cultural groups. These works reflect the changes in a society where, after years of enforced segregation, it is now possible for people of any ethnic group to live in whichever area they choose. People may also send their children to any school in the area where they reside. Through these stories there is also a conscious attempt to promote tolerance and understanding.

Jakey (Beake, 1997) and Dark Waters (Robson, 1995) have as central themes problems of "colored" children relocating to formerly white areas (because parents want children to have a better education or to learn English). The integration of other races into a previously all-white school and the blossoming friendship between a white girl and Indian boy are also themes of Moongirl:

Since the school had been opened to all races, they'd had stacks of black kids. Some traveled in from Soweto or Alex every day, but most had moved into Joeys with their parents, sick of the violence in the townships. There was only a handful of Indian kids, though, and Val would be the only one in Standard 9, as far as she knew (Smith, 1997 p 7).

Julie is attracted to Vallabhah Sooklingham, but her parents and grandmother have difficulty accepting their relationship. Several girls make taunting remarks like "What's it like kissing Curry-Breath."

Both Val and Julie learn to handle jibes and discrimination. However they come to realize that their customs and cultures are very different and that they need time to decide whether they will be able to sustain their relationship and whether marriage will be feasible.

In Knock Knock. Who's There? (Schlebusch, 1995) Susannah, a fourteen-year old so-called "colored" girl is sent by her parents from the township to a school in a formerly white area, but she is determined not to fit in at the new school because she is afraid her friends will think she is a snob and reject her. These problems would not have arisen if it had not been for apartheid, but this issue is mostly avoided.

In Lesley Beake's Jakey (1997) reference is made to the problems caused by the apartheid system. Jakey's mother is employed by Mrs. Donald, who explains to Jakey that she was a member of the Black Sash1 and that she joined because "she wanted to make a difference." "There wasn't much else to do without running the risk of prison or being forced into exile." However, now she has doubts and looking back with hindsight she says "But I think now ...I think I would have done it differently ..." (Beake, 1997 p 45).

1 Black Sash: An anti-apartheid white women's organization founded in 1955, who campaigned against injustice and were so named because of the black mourning sashes they wore when campaigning in public. 
Dark Waters (Robson, 1995) and The Red-Haired Khumalo (Bregin, 1994) are two works where at the outset racism exists between characters. In the former Zack's father wants to sell his house because a "colored" family has moved in next door and in the latter there is antagonism between Chelsea, a white, and Chester Khumalo, who is black and her mother's new husband, and his son. As understanding and respect for the "others" grow the feelings of antagonism disappear and the characters learn acceptance and compromise.

In Dark Waters (Robson, 1995) Zack becomes friends with his new neighbor, Jeremy. However, the idea of having to move from his beloved vlei makes Zack so unhappy that he starts taking drugs. Jeremy is also unhappy because he has left his friends and family behind in the township of Morgenzon and so he too succumbs to the use of drugs. In the process of the two boys' drug-taking problems being resolved the white father comes to appreciate what Jeremy's father has done for his son and is happy to accept him as a neighbor.

In The Red-haired Khumalo (Bregin, 1994) the situation is somewhat different. Chelsea's mother has looked beyond skin-color and seen that Chester Khumalo is a good man and more trustworthy than her first husband, Chelsea's white father. However, she does not have the courage to tell her daughter that she is marrying a black man and when Chester and his son Nkululeko move in with Chelsea and her mother it is the two young people who are antagonistic towards each other. Ultimately they confront their ingrained prejudices and are able to compromise. They even reach the point where they tease each other about their differences. In African societies women have usually been treated as inferiors by their men and have had to do all the housework. The ANC has addressed the problem of gender equality and we see the changing attitudes reflected in the following scene when after Nkuleleko has asked Chelsea what she is going to cook for supper and she reacts with indignation.

"What do you mean me?" she said indignantly. "What's wrong with you, I'd like to know!"

"Cooking is woman's work," he mocked her. "In my culture, women prepare the food. Men eat it."

"Yes, well this is the new SA," she mocked back. "Everyone's equal now. So you might as well start practicing." (Bregin, 1994 p 97)

Sometimes, even though friendships develop between children of different races, these are not on an equal footing. In Pedal Me Faster Marcus is friends with a black boy, Lamla, but the subtext reveals Lamla's subordination to Marcus. Marcus opens a boerewors (hot dog) stand so that he can make enough money to realize his ambition of owning a racing bike. At first "he expected Lamla to work for the fun of it" (Bowie, $1995 \mathrm{p}$ 64) but even though he has to pay him "a couple of rand" when he works, in the end it is only Marcus who gets the new bike and Lamla purchases Marcus' secondhand parts so that he can build a bicycle with Marcus' help (Bowie, 1995 p 100).

Although friendships develop among children from different cultures and creeds very little attention is paid to illuminating the cultures with their specific customs and beliefs. This is very apparent in Neptune's Children (Whitton, 1997) where a diverse group of teenagers spend three weeks on a sailing ship. Fourteen young adults between the ages of 13 and 16 have been selected to take part in a return voyage to Mauritius. They have a common 
purpose and learn to work together in teams mastering the skills needed to sail a ship. New friendships are forged across cultures and creeds. Although there is some discussion of their personal problems-Deleni had been raped the previous year ( $p$ 28) and John's father was a drunkard who often beat John, killed his mother when John was ten years old and a few days later committed suicide (pp 90-91)--there is only one conversation where cultural practices are discussed.

When Mustapho, who is Muslim, explains why he doesn't eat halaal food he says: "I don't have to eat halaal to be Muslim. Some prefer halaal and some don't. If they don't that doesn't make them less Muslim. Halaal food doesn't do a thing for me" (Whitton, $1997 \mathrm{p}$ 66).

The word "prefer" indicates a choice and not a religious norm. While in any religion there will not be uniform adherence by its members to dietary or other practices, it is offensive and insensitive to have Mustapho utter this statement when this is the only culturally specific information given in the book.

\section{Frankness in recent young adult novels}

Most of the English South African novels for young adults are adventures, mysteries or romances which include coverage of topics similar to those found in young adult books published elsewhere, such as peer pressures, child abuse, violence, child kidnapping, drugs, theft, sexual relationships, pregnancy and AIDS. What is interesting though is that since the relaxation of the censorship laws many of these topics are now dealt with more frankly and explicitly. Examples of such frankness are found in Wart by Bonita Case (1995). The awakening sexuality of Talisa, a "colored" girl is discussed and some descriptions are very graphic and explicit. In fact such scenes many even be offensive to some readers. According to the mass media there is greater promiscuity amongst teenagers in the townships and the author's message is that young girls have their lives ahead of them with many more opportunities open to them than before, but sex could dash ambitions and result in AIDS or unwanted pregnancy. Talisa's mother sends her to have tests for pregnancy and AIDS after she admits she has had unprotected intercourse. When both tests are negative Talisa's problems in the story are resolved, but unfortunately the author has given readers incorrect information. This is a pity when so many young people need to be better informed on such an important issue as AIDS. Talisa is very relieved when both tests prove to be negative, but the author has not made it clear that testing negative to AIDS is not proof of not having contacted the disease until six months have passed. Also in spite of the explicit sex scenes and frank discussions she does not point out that a contraceptive such as the pill might be adequate protection against pregnancy but not against AIDS.

The fact that sexual intimacy after a relatively short acquaintance is more likely to be condoned in the townships is reinforced by the behavior of the characters in A Twin World (Mangena 1996). Khomotso says her sister hasn't yet told her "if he has already charmed his way under your dress." She answers her own question by stating: "Four months is a lifetime for anybody without a hormone deficiency. If nothing has happened in four months then it never will" (Mangena, 1996 pp 37-38). 
As a result of the relaxation in censorship one finds examples of explicit language being used. For example in Wart (Case, 1995) when Talisa's mother tries to convince her daughter not to get too involved with her boyfriend she says: "Talisa, you are a beautiful, intelligent girl. You have your whole life ahead of you. Don't throw it all away for some slimy, manipulating, arsehole punk kid with quick talk and slick hair" (Case, 1995 p 128).

Another example of greater frankness is found in The Red-haired Khumalo (Bregin, $1994 \mathrm{p}$ 93). Although it is not uncommon for books about young adults to deal with divorce, it is only when Alex's parents are going to be divorced that her father admits for the first time that he is "gay." Certainly in young adult novels published in South Africa prior to 1994 one would not have found homosexuality being given as a reason for divorce.

\section{Acceptance of African cultural values}

Wart (Case, 1995), The Tale of Two Fathers (Phallas, 1996), A Twin World (Mangena, 1996) and One Bounce (Ntsele \& Smith, 1997) are the only books discussed in this paper which have not been written by white authors. The reason for this is simply because most of the children's and youth authors in South Africa are still white.

In The Tale of Two Fathers (Phallas, 1996) the African author criticizes the apartheid system which "... is a mockery... " and "is making animals out of people" ( $p$ 17). Apartheid is the reason that Thato has two fathers. Benny and his mother loved each other but they could not marry because of "that horrible system" ( $p$ 76). Thato's friendship with Benny is based not only on the expensive gifts that Benny gives him, but also on the values that he learns from Benny. Benny tells him to always do his best and emphasizes that hard work is the key to success. Such didacticism is often found in African literature.

Since 1994 Africans have come to regard their culture with greater pride and Mangena (1996) deals with the acceptance of African identity and culture in A Twin World. Although the characters in this book are all African and it might not be regarded as multicultural in the accepted sense it does contrast African culture with Western culture and for this reason has been included.

Kahinda, who was born in Uganda, challenges Ntsizi about his unquestioning acceptance of many Western cultural values. Kahinda also tells Ntsizi that he can see from his clothes that he has made peace with his oppressor and also that although his "... features and colour are African" culturally, he is "... trying to be someone else... " (Mangena, $1996 \mathrm{p}$ 27). The two friends debate a variety of issues including slavery, Rastafarianism, religion, the use of dagga and marriage customs. Kahinda points out that both he and Ntsizi have fulfilled the "magadi" or "lobola" ${ }^{2}$ obligation and that they and their brides are already husband and wife according to African tradition so he cannot understand that Ntsizi and Khomotso want to have an expensive white wedding in a Christian church followed by a huge reception, which they can ill-afford.

You're an intelligent man, Ntsizi, but on this issue you're proving to be enormously stupid. Only the African has one foot in Africa, the other in Europe and oceans of water beneath him. And struggling to keep his balance. That's why Africans are so

2 Magadi and Lobola: Cattle, goats, sheep or money given by the bridegroom to the bride's family as a formal token of marriage. 
easy to oppress, even by remote control. A people without cultural integrity can have no soul, character or dignity. They live in a twin world of blurred lines and fuzzy images (Mangena, 1996 p 95).

Ntsizi and Khomotso capitulate and opt for a joint wedding with Kahinda and Mpho where they all wear African-style dress made of Chananian cloth. The mens' caftans have the most intricate embroidery around the necks and matching trousers; while the women have "... ankle-length skirts and elegant tops with a loose strip to hang over the shoulder and tiny matching caps that just perched at a cheeky angle on the head" (Mangena, $1996 \mathrm{p}$ 118). The couples are married in the magistrate's court only to obtain the marriage certificates, because these are often required "... in matters of property and ownership and protect parties when things go wrong" ( $p$ 98). Afterwards the small wedding party of close family members has a celebratory lunch of chicken, beer and cool drinks.

\section{Social problems}

The influx of illegal immigrants from other African countries gives rise to numerous social problems which are dealt with in an authentic manner in We Have Our Dreams (Johnson, 1997). Firstly the immigrants face disillusionment when the promised jobs with high wages are found to be non-existent and then they realize that they have been conned by unscrupulous tricksters back at home. Illegal immigrants can only obtain menial work because they have no valid identity documents and they are paid abysmally low wages. Jose and Monami are paid eight rands ${ }^{3}$ for an eight-hour work day which even for illegal immigrants seems an unrealistically low wage (Johnson 1997:8). Obviously they cannot afford decent accommodation and must first make do with a discarded, rusty freight container in a wasteland before moving into the storeroom at the cement factory ( $p 23$ ). Local residents are antagonistic because they begrudge people from other countries getting jobs and working for a pittance as this lessens their own opportunities for finding work for which they will be adequately paid. When immigrants are mugged and their money is stolen they cannot go to the police as they fear deportation.

"You are not a South African. What do you want in our country?"

"Just to work."

"Who told you we need workers here?"

"Nobody. |-1-1"

"You came here to make the labour cheap by collecting peanuts at the end of the month. If you go to the police, they'll deport you immediately. Get up quickly." (Johnson, 1997 pp 46-47)

The theme of people illegally crossing South Africa's borders is a difficult one for an author of a young adult novel to deal with as these young people are breaking the law and also such a situation is of necessity fraught with despair. The only possible resolution to the story is that the young people realise the hopelessness of being illegal immigrants and decide to return to their own countries where despite hardships they will presumably be better off.

3 Eight rand: Less than $\$ 2$ US. 
In Heroes of the Coal Yard (Brandt, 1997) one of the coal boys, Eddy, is also an illegal immigrant from Mozambique. He and mother, father, sister, brother and Uncle Pedro all crossed the border into South Africa and all were caught by a game ranger in the Kruger National Park except Eddy and his uncle who made it to Johannesburg. They have a hard life but have a shack in which to stay and are able to work. Another story which also deals with the working and living conditions of young boys in a coal yard is The Throwaway Kid (Smith, 1997) and the atmosphere which it evokes is Dickensian. Underage children are given work in abject conditions in the coalyard. They are beaten by their employer and given insufficient quantities of awful food.

Saki looked at the stew. It was a colorless, watery mess. Stray chunks of something floated in it, but what those were was anybody's guess. The watery mess had been poured carelessly over a pile of indigestible samp ${ }^{4}$. Saki tried not to think of what Horace had said about stray cats. He ate quickly. If one looked at it as little as possible, it didn't taste too bad, and it was at least warm (Smith, $1997 \mathrm{pp}$ 18-19).

Despite the dreadful conditions the book has a message of hope that one should hang onto one's dreams and have a goal in life. Both this novel and Heroes of the Coal Yard (Brandt, 1997) deal with social problems that were not a feature of Victorian life such as the sniffing of glue by most of the children to find escape from the harsh realities of their world and their dangerous practice of "staffriding"5 on the trains. In fact Spokes is killed staffriding when he falls off the train and lands on the rails (Brandt, $1997 \mathrm{p} \mathrm{130)}$

Many children run away from home because of abuse or neglect and end up as street children in the cities. In Play Music (Bowie, 1996) when Wiseman and Zolani leave their homes they spend a few weeks on the street. They are befriended by Lemmy who explains the dangers on the streets and how to avoid gangs. He helps them to survive by showing them where the nearest soup kitchen is to be found. They also rummage for scraps in rubbish bins outside restaurants.

Retrenchment and affirmative action have affected many people in South Africa in the past few years. In Wart (Case, 1995), Talisa's father is retrenched and her mother explains to Talisa and her sister that it will not be an easy time for their father. "It won't be easy for any of us" (pp 51-52). In Jakey (Beake, 1997) Hendrik de Waal, the white boy whose father beats him, excuses his father's behaviour to Jakey saying:

He's not a bad man, Jake. He loves me really. Only it's hard for him to cope with everything. There's changes at work ... a black man is getting the promotion Dad wanted. Dad's not really a racist - honestly he's not! But he needed that promotion. (Beake, 1997 p 67)

Another book which has as one of its themes child abuse is The Bughouse (Milne, 1997). The author's treatment of abuse in this story is, however, not credible and she never comes to grips with the issues she raises. Mike suffers physical abuse by his stepfather on numerous occasions because he will not succumb to his sexual advances and eventually he

4 Samp: Type of corn.

5 Staffriding: Practice of hanging onto the outside of a train to avoid paying the fare. 
runs away from home. However when he is found after a few days suffering from a high fever he is left in the care of his mother's neighbors "... while she [his mother] and Stepdad are overseas for a year, trying to sort things out" (Milne, 1997 p 140).

The widespread crime and violence in the country is also reflected in several of the novels under discussion. In One Bounce (Ntsele \& Smith, 1997) Kop and Hale live next door to each other and have been friends since childhood. Hale is still at school but now his friend Kop is working for car thieves (known as "gents") and stealing four cars a week for which he receives thousands of rand. "Now Kop delivered cars for magents, and sometimes Hale thought his mother knew that Kop wasn't going to school any more, that the money for his beautiful clothes didn't come from his mother" (Ntsele \& Smith, 1997 p 17).

Kop spends his ill-gotten gains on liquor, parties and on designer clothes and gold jewelry for himself and his girlfriend. Hale attends a big party, known as a "bash," in Soweto with Kop and his friends, but at one o'clock in the morning when most of the teenagers are drunk and staggering many of the boys pull out guns and start firing them. Soon afterwards when the gents and their girlfriends attend the funeral of one of the gangsters guns are fired again.

...Kop was pulling out his gun at the same time as the other gents were pulling out theirs and lifting them to the sky, all at once. And then there was the shooting that seemed to carry on and on and made Hale scream without even being conscious of the level of his fear. People scattered in all directions, running madly for their buses and cars. Some tripped over headstones as they fled (Ntsele \& Smith, 1997 p 71).

This time Kop is hit and killed by a bullet.

Jakey's stepfather, Tata, is killed by "skollies" 6 who take his wages and Christmas bonus. They leave "... him lying all in a heap at the side of the road" (Beake, 1997 p 6). In Heroes of the Coal Yard Eddy's uncle is attacked by two "tsotsis"7 with a knife who stab his arm and rob him of his groceries and money (Brandt, $1997 \mathrm{p} \mathrm{22).} \mathrm{Thieves} \mathrm{also} \mathrm{pilfer} \mathrm{sacks} \mathrm{of}$ coal from the coal yard and Mr Genuka, the owner of the coal yard, is attacked outside a shebeen by three thugs with knives and pangas who want his money (pp 102-103).

In Pedal Me Faster (Bowie, 1995) thieves with a knife take the cash boxes from the hot-dog stand while in Play Music (Bowie, 1996) Wiseman, Zolani and Lemmy are attacked by a gang of Satanists who capture Lemmy because they intend to sacrifice him.

Poverty has led not only to increased crime and violence but also to an increase in the numbers and size of informal settlements which are found all over the country. In Wart (Case, 1995) passing mention is made to one of these settlements known as Crossroads.

There was a news item on tv about the people living in shacks in Crossroads. Many of them no longer had homes, their houses were blown away by the wind. It was freezing that night. In my thick pyjamas and bed with three blankets, I was freezing. And I couldn't stop thinking about those people. They were outside in the cold. They had nowhere to go. And they definitely didn't have three blankets to keep them warm. After a while I went to talk to my mother: I told my mother what was

6 Skollies: Hoodlums

7 Tsotsis: Hoodlums 
bothering me. I asked her if anyone was helping those people. "But what can you do?" she said, with a sigh. "What can you do?" (p 29)

Unfortunately social problems of such magnitude do not have easy or swift solutions and stories can only reflect what is happening in society without offering solutions.

\section{Complex young adult novels}

Two books, The Joining and The Secret Song are both well-written novels which have depth and complexity of plot and deal with important issues such as indigenous people living in harmony with the environment and of people's need for knowledge for empowerment.

In The Joining (Slingsby, 1996) the author uses the device of a time warp to move between different cultures. On a superficial level there is the friendship between the children of different races, but when they go back in time to a different era many thousands of years ago and meet with the indigenous San people they are quickly accepted by the San in spite of their very different appearance. The reader learns about the values of the San and something of their culture though the explanation of their rock paintings or "joinings" which were created to portray the connections between humans and animal or spirit world. A people who had very definite cultural values. Only those people who meet certain criteria are allowed to paint joinings. The San are also depicted as living in harmony with nature not destroying the environment in the way that supposedly developed people of the present age do. In Pedal me faster (Bowie, 1995) thieves with a knife take the cash boxes from the hot-dog stand while in Play music (Bowie, 1996) Wiseman, Zolani and Lemmy are attacked by a gang of Satanists who capture Lemmy because they intend to sacrifice him.

Poverty has led not only to increased crime and violence but also to an increase in the numbers and size of informal settlements which are found all over the country. In Wart (Case, 1995) passing mention is made to one of these settlements known as Crossroads.

There was a news item on TV about the people living in shacks in Crossroads. Many of them no longer had homes, their houses were blown away by the wind. It was freezing that night. In my thick pajamas and bed with three blankets, I was freezing. And I couldn't stop thinking about those people. They were outside in the cold. They had nowhere to go. And they definitely didn't have three blankets to keep them warm. After a while I went to talk to my mother: I told my mother what was bothering me. I asked her if anyone was helping those people. "But what can you do?" she said, with a sigh. "What can you do?" (p 29)

Unfortunately social problems of such magnitude do not have easy or swift solutions and stories can only reflect what is happening in society without offering solutions.

\section{Complex young adult novels}

Two books, The joining and The secret song are both well-written novels which have depth and complexity of plot and deal with important issues such as indigenous people 
living in harmony with the environment and of people's need for knowledge for empowerment.

In The Joining (Slingsby, 1996) the author uses the device of a time warp to move between different cultures. On a superficial level there is the friendship between the children of different races, but when they go back in time to a different era many thousands of years ago and meet with the indigenous San people they are quickly accepted by the San in spite of their very different appearance. The reader learns about the values of the San and something of their culture though the explanation of their rock paintings or "joinings" which were created to portray the connections between humans and animal or spirit world. A people who had very definite cultural values. Only those people who meet certain criteria are allowed to paint joinings. The San are also depicted as living in harmony with nature not destroying the environment in the way that supposedly developed people of the present age do.

In The Secret Song (Williams, 1997) Bosman, a young man wanted by the police, runs away but to the place of his birth to try and find his origins. He is befriended by Silas and Sophia on his way to Koombu. In Koombu there are mysteries to be solved. The young colored people are living in ignorance and bondage - the white people in fear-but with the changes in the country and the forthcoming elections the old ways can no longer hold sway and with knowledge of freedom comes empowerment.

\section{Conclusion}

The books analyzed reflect the changes in South African society, but are presented mainly from a white perspective because the majority of the authors are white. Only when we have more authors from other cultures writing for young adults will we have a true reflection of the social problems and cultural values existing throughout South African society.

\section{References}

Beake, Lesley. (1997), Jakey. Cape Town: Tafelberg.

Bowie, Beryl. (1995). Pedal me faster. Cape Town: Maskew Miller Longman. (Young Africa series: 1995 winner)

Bowie, Beryl. (1996). Play music. Cape Town: Maskew Miller Longman. (Young Africa series)

Brandt, Marianna. (1997). Heroes of the coal yard. Manzini, Swaziland: Macmillan.

Bregin, Elana. (1994). The red-haired Khumalo. Cape Town: Maskew Miller Longman. (Young Africa series: 1994 winner)

Brown, A. (1983). Social values in children's literature. Review, 11(2), 8-13.

Case, Bonita. (1995). Wart. Cape Town: Tafelberg.

Hofmeyr, Dianne. (1994). Boikie, you better believe it. Cape Town: Tafelberg. (Sanlam prize for youth literature 1994, gold) 
Hollindale, Peter. (1992). Ideology and the children's book. In Peter Hunt (Ed.), Literature for children: contemporary criticism (pp. 18-40). London: Routledge.

Johnson, Anthony K. (1997). We have our dreams. Manzini, Swaziland: Macmillan.

Machet, M.P. \& Bester, M. (1990). Sociology of literature as applied to children's literature. South African Journal of Library and Information Science, 58(4), 370-376.

Macleod, A.S. (1975). A moral tale: children's fiction and American culture, 1820-1860. Hamden, Connecticut: Archon.

Mangena, Mosibudi. (1996). A twin world. Cape Town: Maskew Miller Longman. (Young Africa series)

Milne, Lesley. (1997). The bughouse. Cape Town: David Phillips.

Mitchell, C. \& Smith, A. (1996). Reading production: investigating social changes as inscribed into South African young adult literature. South African Journal of Library and Information Science, 64(2), 86-91.

Ntsele, Andrew \& Smith, Janet. (1997). One bounce. Cape Town: Maskew Miller Longman. (Young Africa series: 1997 winner)

Phallas, Dave. (1996). A tale of two fathers. Cape Town: Kwela Books.

Robson, Jenny. (1995). Dark waters. Cape Town: Tafelberg.

Robson, Jenny. (1996). One magic moment. Cape Town: Tafelberg.

Schlebusch, Anne. (1995). Knock, knock who's there? Cape Town: Maskew Miller Longman. (Young Africa series 1995 winner)

Shannon, P. (1986). Hidden within the pages: a study of social perspective in young children's favourite books. Reading Teacher, 39, 656-663.

Slingsby, Peter. (1996). The joining. Cape Town: Tafelberg. (Sanlam prize for young literature 1996)

Smith, Gail. (1996). Moongirl. Cape Town: Maskew Miller Longman. (Young Africa series: 1996 winner)

Smith, Gail. (1997). The throwaway kid. Cape Town: Tafelberg.

Van der Walt, Thomas. (1994). A portrayal of South African society in contemporary realistic English South African youth literature. In Maria Nikolajeva (Ed.), Voices from far away: current trends in international children's literature research (pp. 61-79). Stockholm: Centrum för barnkulturforskning, Stockholms universitet.

Whitton, David. (1997). Neptune's children. Manzini, Swaziland: Macmillan.

Williams, Michael. (1997). The secret song. Cape Town: Tafelberg. 